\title{
John Duns SCOTUS AND THE ONTOlOGY OF MIXTURE
}

\author{
Lucian Petrescu
}

\begin{abstract}
This paper presents Duns Scotus's theory of mixture in the context of medieval discussions over Aristotle's theory of mixed bodies. It revisits the accounts of mixture given by Avicenna, Averroes, and Thomas Aquinas, before presenting Scotus's account as a reaction to Averroes. It argues that Duns Scotus rejected the Aristotelian theory of mixture altogether and that his account went contrary to the entire Latin tradition. Scotus denies that mixts arise out of the four classical elements and he maintains that both the elemental forms and the elemental qualities are lost in the mixture. Consequently, he denies the distinction between the process of mixture and that of substantial change through generation and corruption. The reassessment of Scotus's account modifies the current historical representation of this discussion, inherited from Anneliese Maier.
\end{abstract}

Late medieval philosophers expended a great amount of effort on Aristotle's theory of mixture and developed various accounts of how mixts arise out of the four Greek classical elements. ${ }^{1}$ John Duns Scotus held a radical set of theses on the theory of mixture: that the elements are not kept in the mixts neither with respect to their form, nor with respect to their qualities; ${ }^{2}$ that a single element can give rise to a mixt; ${ }^{3}$ that mixts are not generated through the mutual action of the elements; and that they cannot be generated out of the four elements at all. ${ }^{4}$ Consequently, he rejected Aristotle's theory of mixture as a process distinct from generation,

\footnotetext{
${ }^{1}$ Following a common practice in the literature, I use the old English word "mixt" for the result of the mixture, mixtum, and "mixture" for the process, mixtio. The current English sense of mixture, which is closer to Aristotle's synthesis, a juxtaposition of elements (or its result), will not be used.

2 "Ideo est alia opinio, quam teneo, quod formae elementares non manent in mixto secundum suas essentias, nec eorum qualitates" (Lect. II, d. 15, q. un., 26).

3 "Similiter ex uno elemento generatur mixtum" (Lect. II, d. 15, q. un., 29).

4 "Credo autem quod nunquam mixtum generatur ex quattuor elementis mutuo agentibus" (Lect. II, d. 15, q. un., 30). "Ideo dico quod nunquam est necesse quod genereretur mixtum ex quatuor elementis concurrentibus, etiamsi concurrant per virtutem divinam, vel qualitercumque, nunquam ex eis generatur mixtum" (Rep. 2A, d. 15, q. un., 6).
} 
corruption, or alteration. This essay will present his account and argue that it went contrary to an entire tradition that endured until Padouan Averroism and sixteenth-century Thomism.

Current knowledge of the development of this discussion in Latin philosophy rests on Anneliese Maier's classic study "Die Struktur der Materiellen Substanz" $(1952,1-140) .{ }^{5}$ Maier studied most of the works from the fourteenth century that were available to her at that time and followed the medieval problem of "whether the elements remain in the mixt." I seek here a reassessment of Duns Sctous's position in the historical development of this discussion and argue that his account was more original than previously thought. Maier noted the importance of Duns Sctous's account for the subsequent views of authors such as William of Ockham or Gregory of Rimini, but she still treated him as developing a Thomist view on mixts. She speaks of a "clarification" of the Thomist theory (107) and of a "Thomist-Scotist view" (111). To appreciate Scotus's novelty, a revision of the main solutions provided within Latin Aristotelianism is needed. I will thus revisit four main authors: Avicenna, Averroes, Thomas Aquinas, and Duns Scotus.

In the first section, I set the stage by summarizing the problem posed by Aristotle's conception of mixts. In the second section, I present the key positions inherited by the Latins from Arab philosophy. In the next two sections, I present Thomas's and Scotus's views. I end with a number of conclusions on Scotus's position.

\section{The Aristotelian Theory of Mixture}

The development of the ontology of mixture in Latin philosophy took place in commentaries to Aristotle's De Gen. et corr., in lectures on the second book of Peter Lombard's Sentences that discuss the creation of matter and organisms, in some elucidations of the composition of material substance from De Coelo, Physica, and Meteorologica IV, and in the medical literature on Avicenna's Canon and Galen's doctrine of the humors. While these places sometimes bring about important elaborations and are of great significance for the historical transmission of ideas, the core of the late medieval doctrine of mixts was formulated with respect to chapter 10 of book I of Aristotle's De Gen. and with respect to Averroes's position.

Mixts are sublunary bodies composed of the four primary elements (fire, water, earth, air). They make up the entire material world and are the subjects of natural science. In their ontological representation, the doctrine of hylomorphic composition intervenes at every level of the physical architecture: cats have matter and form, flesh and bones have matter and form, and the four elements themselves have matter and form. The need to describe mixed bodies in terms of metaphysical parts, as

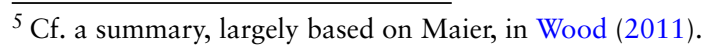


composites of form and matter, gave rise to an enduring medieval debate: the question of whether the four elements are kept in the mixt, and if so, how. De Gen. I, 10, 327b 1-6 presents the original puzzle: either the elements are kept in the mixt, and in this case we do not have a proper case of mixture, but a mere juxtaposition of elements, a mechanical mixture (synthesis); or they are not kept in the mixt, and in this case we have a simple case of corruption and generation of a new substance. Aristotle's own solution was to posit mixture as a type of substantial transformation different from generation, corruption, or alteration. In the operation of mixture, elements are not quite preserved but also not quite destroyed (quodammodo manent et quodammodo non, repeated the Latins). Aristotle explains this ambiguous persistence by appealing to his distinction between actual and potential being. According to the most widespread Latin reading of this text, elements are kept potentially or virtually, not in actu, in the mixt (327b 22-31). To use Aristotle's term, they keep their dynamis (327b 30 , translated as virtus or potentia). This was meant to explain both their permanence in the mixt and their regeneration when the mixt is dissolved. ${ }^{6}$

The Greek commentators on Aristotle developed important accounts of mixture, as did the Stoic tradition and Neoplatonic authors. The most consequential of the ancient commentator's accounts was that of John Philoponus, through its influence on Arab philosophy. However, Latin philosophers largely ignored the ancient accounts until their rediscovery in the sixteenth century (or referenced them occasionally through the Arab filter), and therefore they fall out of my scope here. When the views of the Greek commentators are reconsidered in the Renaissance, the opinions of Latin philosophers on mixture are already formed. Giacomo Zabarella, for instance, will not shy away from claiming that both Alexander of Aphrodisias and John Philoponus actually support Averroes. ${ }^{7}$ Regarding the Stoics, aside from problems of transmission, their commitment to a "body going through body" theory-the idea that different substances are able to exist in the same place at the same time-would have been too far from Aristotle's views to raise any significant interest. ${ }^{8}$

The only sources used actively by Latin philosophers when discussing mixture were thus Aristotle, Averroes, and Averroes's reading of Avicenna.

\footnotetext{
${ }^{6}$ I am only concerned here with a basic account that medieval philosophers would have been familiar with; this reductive summary cannot give justice to the complexity of Aristotle's account or to the extensive literature devoted to it. Recent discussions are provided by Frede (2004) and by Cooper (2004). I also rely on Joachim (1904; 1922), Sorabji (1988, 60-78) and Rashed's (2005) exhaustive commentary from his Budé edition of Aristotle.

${ }^{7}$ Zabarella (1604, 240a-241a) ("Confirmatio eiusdem sententiae authoritate graecorum interpretum").

${ }^{8}$ See Sorabji $(2005,290-315)$ for a fast and useful presentation of the ancient commentators' views on mixture, with texts and references to bibliography. Very few Greek commentaries on De Gen. have survived: Philoponus's, and through it, fragments of Alexander's, and Alexander's De mixtione, mostly concerned with refuting the Stoic position. See Todd (1976), Hahm (1985), Lewis (1988) and De Haas (1999).
} 
We can use the exegesis of the sixteenth century philosopher Giacomo Zabarella as a historical guide into the positions known and developed by Latin Aristotelianism. Zabarella wrote a Liber de mistione toward the end of the philosophical lifespan of the Aristotelian theory of mixts. $\mathrm{He}$ divided the positions available to him between the four authors mentioned: Avicenna, Averroes, Saint Thomas together with "the rest of the Latins," and Duns Scotus. These authors provided for him a complete panorama of possible solutions. ${ }^{9}$

The technical question posed by the commentators, according to Zabarella, was: are the elements kept in the mixt at the level of their (substantial) form, or are they kept at the level of their qualities? ${ }^{10}$ Zabarella recited Avicenna's position (1), who held that the elements are kept in the mixt at the level of forms, while their qualities, though also kept, are "remitted" (remittae, castigatae, diminutae, and fractae were some of the terms used). ${ }^{11}$ "Remission" is a technical term that expresses a reduction of the intensity of a quality, coined in order to allow the interaction of elemental qualities: in their highest degree, the elemental qualities are contrary to each other in couples of two (wet is contrary to dry, hot is contrary to cold), and thus cannot interact or combine-hence the need for their remission. Averroes (2), the second opinion recited by Zabarella, proposed the remission of both elemental forms and qualities. ${ }^{12}$ Thomas Aquinas (3) held that the elemental forms were entirely destroyed in the mixt and that only their remitted qualities were kept. ${ }^{13}$ Finally, (4) Duns Scotus held that both the substantial form and the elemental qualities were destroyed in the mixt. ${ }^{14}$

\footnotetext{
${ }^{9}$ Liber de mistione, in Zabarella (1604, 231-245) ("Avicennae opinio," "Averrois opinio, et adversus Avicennam disputatio," "Scoti opinio," "Aliorum latinorum opinio"). Zabarella quotes Scotus as the third opinion and Thomas et al. as the fourth opinion. I reverse the positions, for concerns of chronology and conceptual coherence.

${ }^{10}$ Zabarella $(1604,231 \mathrm{a}-\mathrm{b})$ : "Hac igitur de re est nobis in praesentia disputandum, ut omni, si fieri possit, difficultate sublata definitio mistionis clara, \& perspicua reddatur; quam bene intelligere non possumus, nisi ea, quae tetigimus, dubia solvantur: haec autem duo sunt potissime, unum de formis elementorum, an serventur in misto, alterum de eorundem qualitatibus, quas in praesentia statuimus non esse formas elementorum, sed accidentia consequenta. Repugnantia autem praedicta traxit alios in varias opiniones, quae mihi videntur quattuor esse ad summum."

11 Zabarella (1604, 231b): "putavit enim Avicennas formas elementorum remanere in misto integras, \& nulla ex parte laesas; qualitates vero manere quidem, non tamen integras, sed castigatas, \& fractas ob mutuam inter se actionem, \& passionem."

12 Zabarella (1604, 232a): "Secunda est Aver. opinio . . dicit, tam formas substantiales elementorum, quam qualitates manere acto in misto, fractas tamen omnes, \& castigatas, \& ad mediocritatem redactas."

${ }^{13}$ Zabarella (1604, 233b): "Quarta sententia est, ut mihi videtur, caeterorum latinorum, qui de formis elementorum Scoto consentientes dicunt, eas nullo modo servari, neque integras, neque refractas; sed in qualitatibus ab eo discrepant, has enim putant in misto remanere fractas, \& ad mediocritatem redactas." Zabarella quotes Marsilius of Inghen, Thomas, Aegidius Romanus, Ludovico Boccadiferro, "and other recentiores."

${ }^{14}$ Zabarella $(1604,233 a)$ : "putavit Scotus \& formas \& qualitates elementorum in mistione penitus interire, \& novam misti formam generari, \& novam qualitatem, quae est temperatura misti.”
} 
For the sake of comprehensiveness, these four positions can be represented as follows:

\begin{tabular}{lll} 
Opinions & $\begin{array}{l}\text { Elemental substantial } \\
\text { forms in the mixt }\end{array}$ & $\begin{array}{l}\text { Elemental qualities in } \\
\text { the mixt }\end{array}$ \\
\hline Avicenna & + &,+ but remitted \\
Averroes & + , but remitted & + , but remitted \\
Thomas Aquinas & - & + , but remitted \\
John Duns Scotus & - & -
\end{tabular}

In what follows, I defend the historical sketch proposed by Zabarella by presenting the accounts of these four authorities.

\section{The Arab Heritage}

The classical place of reference for the medieval discussion is a digression from Averroes's comment 67 on Book III of De Coelo, in which Averroes presents Avicenna's opinion alongside his own view. ${ }^{15}$ Although Avicenna's view was available from other places (Sufficientia, I, 10, i.e. Physics I, 10 from the Shifâ, and De Gen., 6), medieval philosophers quoted Avicenna's view from Averroes. ${ }^{16}$

According to Averroes, Avicenna thought that the elementary forms are present in the mixt in the same way in which they are present in the elements. Because forms cannot undergo a variation of degrees (non dividuntur in magis et minus), they cannot interact directly; consequently, mixture has to happen at the level of the elementary qualities. Will the qualities then be kept in full or remitted? Averroes developed two arguments here.

(1) Keeping the same non-remitted qualities of an element in the mixt necessarily entails keeping its form. Keeping, for instance, non-remitted heat and dryness, entails necessarily keeping fire too, which is nothing else than the union of heat and dryness in summo. And if we keep the form

\footnotetext{
15 There is another text on mixture in an insertion at the end of Averroes's Middle Commentary to De Generatione et corruptione, but this passage is considered an interpolation; however, it is present in the Latin manuscript tradition. For details, see Eichner's (2005, 134-187) excellent commentary. References to vol. V of the Junta edition (Averroes 1562, "editio Juntina secunda") are: In III De Coelo, comm. 67, 226b-227c, and Media expositio in I De Gen., comm. 82-90, 368d-370d.

${ }^{16}$ Avicenna (2009, 67-70): "So the essential forms of these [ingredients] remain conserved, while the accidents by which they interact so as to bring about an alteration change and undergo alteration such that as any excess that is in any of its individual [ingredients] decreases until the quality of the overpowering [ingredient] stabilizes in it, falling below the point where it overpowers." Avicenna provides a much more extended discussion in his De Generatione et corruptione (1987, 56-78). For details on Avicenna's account, see Van Riet's commentary in Avicenna (1987) and Stone (2008). The text from Physics I was known as part of the Sufficientia translated at Toledo in the twelfth century; the second text from De Generatione is attested from the end of the thirteenth century; the first attestation of the complete collection of the Physics of the Shifâ dates from 1338. See D'Alverny (1961) and van Riet (1999).
} 
of the element, there will be no mixt to speak of: a composite substance is united in virtue of its substantial form; therefore, having distinct elemental parts in actu in the composite would destroy its unity and result in juxtaposition. ${ }^{17}$

(2) Avicenna had proposed instead that only remitted qualities remain. In this case, the elemental form need not necessarily follow the qualities, because their intensity is reduced.

Averroes developed the following criticism of Avicenna's view on this point. Remission happens through a loss of ingredient parts, called degrees ( $\mathrm{gradus}$ ). If we interpret the remission of qualities in terms of a subtraction of parts (or degrees), there is no obvious limit to that subtraction, and we could end up with a substance devoid of all quality. If one part can be removed, so can any other part, and so can the whole. Averroes calls this principle pars et totum idem habent judicium. A substantial form devoid of all qualities, say fire without heat, is obviously impossible. For Averroes, the substantial form necessarily entails some elemental qualities proper to that form: stripping down the qualities would leave nothing. ${ }^{18}$

There is one solution left, which Averroes proposes: both the elemental forms and qualities are remitted secundum medietatem. Applying remission to both elemental forms and elemental qualities is a consequence of their inseparability for Averroes. Averroes argues that the elemental forms need to be kept because they act as a necessary intermediary between prime matter and the final form of the mixt: prime matter cannot be informed directly by the form of the composite body, but only through the mediation of elemental forms. ${ }^{19}$ Although the final introduction of the new form is

\footnotetext{
${ }^{17}$ In III De Coelo, Comm. 67, 227rb, 115-120 (Averroes 2003): "Et cum hoc latuit Avicenne, et concessit quod forme substantiales non dividuntur in magis et minus, dixit quod hec elementa non miscentur nisi secundum qualitates eorum non secundum substantias; et ex hoc contingit magnum impossibile, scilicet ut elementa sint in composito in actu propter quod compositum non habebit unam formam substantialem."

${ }^{18}$ Averroes (2003), Comm. 67, 227rb, 127-137: "utrum igitur si forme elementorum relinquuntur in composito in suis perfectionibus, utrum similiter relinquantur in suis qualitatibus propriis suis formis aut non, verbi gratia in calore aut frigore; si autem remanent, contingit ut in composito sit ignis in actu: ignis enim non est ignis in actu nisi calore et siccitate que sunt in summo. Si autem amittant quandam partem istarum qualitatum propter mixtionem, et forme tantum remanent perfecte, possibile est ut forme eorum denudentur ab hiis qualitatibus secundum totum: pars enim et totum idem habent iudicium, idem enim iudicium est partis et totius; et totum hoc est impossibile." He ends with one of his usual attacks against Avicenna: "paucitas vero exercitationis istius viri in naturalibus et bona confidentia in proprio ingenio induxit ipsum ad istos errores." Duns Scotus did not think that Averroes's argument from idem est iudicium partis et totius was valid (Lect. II, d.15, q. un., 3). He points out that, from the fact that the qualities can be remitted, it does not follow that they can be remitted entirely, until nothing is left but a form devoid of all qualities. Scotus argues that a substance has a minimum set of qualities without which it cannot exist.

${ }^{19}$ Averroes (2003), Comm. 67, 227ra, 101-105: "necesse est, cum ex eis generatur una forma, ut corrumpantur forme eorum secundum medietatem, quoniam si corrumpantur secundum totum, tunc prima materia reciperet primo et essentialiter omnes formas, et non reciperet formas compositorum mediantibus istis corporibus."
} 
the work of an external agent, the elements too act as a material cause, preparing the matter of the mixt.

Averroes's position is uncomfortable because of the generally shared principle that substantial forms do not admit variation. Substantial forms, throughout Latin Aristotelianism, are understood as simple, non-decomposable forms that give a definition of a substance (its essence) and explain its assignation to a species. The text of reference here is Aristotle's definition of formal cause as "an account of the essence" of a substance from Phys. II, 3, 194b 27. A variation of species entails a variation of forms and vice versa. How to understand then that fire is half fire in a mixt? ${ }^{20}$

Given this constraint, Averroes is reduced to positing an intermediate ontological category for elemental substantial forms. He holds that elemental forms are not as perfect as the substantial forms of mixts; their way of being (esse) is a medium between a substantial form and an accident. ${ }^{21}$ Elemental forms, although they are substantial because they give the formal definition of the substance of the element, are also accidental because they admit a variation of degrees. The variation of forms, and thus their "accident-like" feature, accounts for the fact that a new form arises from their mixture, just in the way that countless median qualities arise from mixtures of other qualities (e.g., lukewarm water from cold and heated water).

Averroes held, as far as I understand him, the following position: elemental forms act as substantial forms when they inform the pure elements, but at the same time those same forms act as accidental forms when they inform the mixt. Elemental fire, in its pure state, has the substantial form of fire, which makes it what it is; but when combined in a mixt, say in human flesh, the elemental form of fire loses its status of substantial form and becomes an accidental form of the mixt, subordinated to the forma mixti: fire becomes animal heat. To sustain this argument, Averroes appeals to the distinction between potentia and actus in the esse of the elements. When the elements are combined, their actuality is changed in the new forma mixti, but their potency is left intact. The substantial form of fire is in actu and acts as a substantial form only when it informs elemental fire; in the mixt, the same form is only present in potentia-that is, as an accidental form, it retains the potency of becoming a substantial form again when the mixt is resolved into its components. I base this interpretation on one of Averroes's clearer statements on the permanence of the ingredients in the mixt, to be found in his Middle Commentary to De Gen. I:

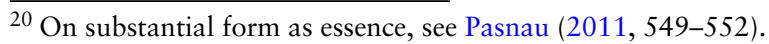

${ }^{21}$ Comm. 67, 227ra-rb, 105-113: "Si igitur aliquis dixerit quod sequitur ex hoc ut forme eorum substantiales recipiant magis et minus (et hec est dispositio accidentium non formarum substantialium ... ), dicemus quod forme istorum elementorum substantiales sunt diminute a formis substantialibus perfectis, et quasi suum esse est medium inter formas et accidentia; et ideo non fuit impossibile ut forme eorum substantiales admiscerentur, et proveniret ex collectione earum alia forma, sicut cum albedo et nigredo admiscentur, fiunt ex eis multi colores medii."
} 
Since we have already stated that some things exist potentially while others exist actually, we see that, as far as the actual state of the miscibles at the time of their mixture is concerned, the resultant from their mixture is other than what they were before they were mixed; and as far as their potential state is concerned, each of them remains just as it was before they were mixed. $(1958,62)$

However, Averroes's claim that one and the same form can undergo a category change from accident to substance and back remains highly problematic. The Latins criticized heavily this ontological creativity; they will never admit that substantial forms can undergo variation.

Medieval Latin authors rejected the opinions of both Avicenna and Averroes unanimously. But the Arab account endured not only as a heterodox opinion against which most of the Latins could develop their variation of hylomorphism: it also gave the fundamental causal understanding of the combination of elements through the remission of their qualities. The remission (and intention) of accidental forms or qualities is an issue that is much debated in both Ancient and Latin philosophy, with a known momentum in the fourteenth century. But the discussion on the intension and remission of forms in Latin philosophy-whether the variation happens in the quality itself (Henry of Ghent) or in the subject sustaining the quality (Thomas Aquinas), whether variation happens at all, or what happens is a succession of different forms (Godefrey of Fontaines) or an addition of parts to the same form (Richard of Middletown, Scotus, Ockham)-is secondary here. ${ }^{22}$ The lesson learned from Averroes was that the variation needed for the elements to mix happens at the level of the elemental qualities, as accidental forms. The concept of remission reduced the natural incompossibility of elemental forms or qualities and made them able to combine and contribute to the introduction of the forma mixti. Although the Latins reacted strongly against the notion of the permanence of the elemental forms in the mixt, they all kept the causal account provided by the Arab interpretation, which entailed a permanence of qualities-until Duns Scotus.

\section{Saint Thomas and the Latins}

Aside from a couple of brief statements in his major writings, Thomas Aquinas wrote a small piece on mixture, titled De mixtione elementorum. ${ }^{23}$

\footnotetext{
22 On intensification and remission of forms in ancient philosophy, see Sorabji $(2005,316-$ 326). For the medieval discussion, see inter alia Maier (1968), Sylla (1991), and Dumont (2009). On Scotus's account (an addition theory), see Cross (1998, Ch. 10).

${ }^{23}$ De mixtione elementorum ad magistrum Philippum de Castro Caeli, in Thomas Aquinas (1882-, 43: 153-157). For other discussions of Thomas on mixture, see Qdl. I, a. 6 ad 3, Sum. Theol. q. 76 a. 4 ad 4, De anima q. 9 ad 10, De Potentia, q. 5, a. 7. See Denis (1954, 160-164) for a discussion of these texts and of Thomas's apparent hesitations. The Leonine editors
} 
Thomas argues in this late text that the permanence of the elements is not realized at the level of the elemental forms at all (against Avicenna and Averroes), but at the level of their qualities or powers. Thomas thought that the Averroist intention and remission of elemental forms brings about more problems than it solves. ${ }^{24} \mathrm{He}$ thought that elemental forms are above all substantial forms (although, one should note, Aristotle's own position on this matter is less than clear). As such, attributing a variation to them went contrary to a number of Aristotelian texts, expressed in the medieval dictum that forms are like numbers (formae sint sicut numeri). ${ }^{25}$ Saint Thomas thus provided the classical argumentation against the solutions of the Arabs that would become a point of reference for subsequent treatments.

Against Avicenna's position of keeping the elemental forms, Thomas argues that it would entail a heterogeneous mixt. (1) Substantial forms need a matter properly disposed to receive them. (2) Matter, however, cannot be at the same time properly disposed to receive the form of fire and the form of water, because these dispositions are mutually exclusive. It is impossible for prime matter to support various different elemental forms at the same time and in the same way. (3) Hence different elemental forms would have to inhere in different parts of matter, which means that they would have to be received in quantified matter (quantity being the accident that gives parts). (4) But a quantified part of matter joined with a form makes a complete physical body on its own, to which it would be superfluous to add another form. A multiplicity of forms in matter consequently entails a multiplicity of bodies, which invalidates the homogeneity of the mixt. ${ }^{26}$

Averroes, as we have seen, wanted to avoid this consequence by defending the remission of forms. Thomas rejects this position with two arguments: (1) Holding that substantial forms undergo variation would entail that forms are divisible (one can add or extract degrees to a certain form). Divisibility in turn entails that forms participate in a continuous

date the small treatise on De mixione elementorum as post 1270; I take it to be the mature expression of Thomas's views. See also Wippel (2000,350-351), who finds that Thomas's early sympathy for the Averroist position was ultimately rejected because of concerns over the unicity of form. Cf. Bobik (1988, 103-126), a close (non-historical) commentary of the text. ${ }^{24}$ De mixt. elem., 53-57: "Quidam autem utrasque rationes uitare uolentes, in maius inconueniens inciderunt: ut enim mixtionem ab elementorum corruptione distinguerent, dixerunt formas substantiales elementorum aliqualiter remanere in mixto."

${ }^{25}$ Metaph. VIII.3, 1043b 33-1044a 9 and Thomas, In VIII Metaph., lect. 3.

${ }^{26}$ De mixt. elem., 18-36: "Impossibile est enim materiam secundum idem diuersas formas elementorum suscipere; si igitur in corpore mixto forme substantiales elementorum saluentur, oportebit diuersis partibus materie eas inesse. Materie autem diuersas partes accipere est impossibile nisi preintellecta quantitate in materia, sublata enim quantitate substantia indiuisibilis permanet, ut patet in I Phisicorum [185b 11-18]; ex materia autem sub quantitate existente et forma substantiali adueniente corpus phisicum constituitur: diuerse igitur partes materie formis elementorum subsistentes plurium corporum rationem suscipiunt. Multa autem corpora impossibile est esse simul; non igitur in qualibet parte corporis mixti erunt quatuor elementa: et sic non erit uera mixtio, sed secundum sensum, sicut accidit in aggregatione corporum insensibilium propter paruitatem." 
motion, just like qualities, by acquiring or losing degrees. However, forms cannot be gained and lost through a continuous motion, for this would invalidate the very concepts of the generation and corruption of individual substances, which happen at discrete moments. (2) The second argument: substantial forms cannot act on each other in order to get remitted because they are not, in fact, contrary to one another. Only accidents can be contrary to one another (e.g., a horse is not contrary to a cow, but a horse cannot be black and white at the same time).

Unlike substantial elemental forms, elemental qualities are contrary to each other and therefore can undergo intention and remission, combine, and generate a median quality. Although it inheres in the mixt, the median quality is causally produced by the combination of the extreme qualities, just like in the Arab account. In this way, the elements still act as a material cause. Thomas holds that the median quality is the disposition of matter to receive the forma mixti (e.g., heat is a material disposition proper to receive the form of mixed fire). The difference between the median quality and the extreme qualities is not one of species, but only one of degrees; one can retrieve the original elemental forms by varying the necessary qualities to the extreme degrees. In this sense, one can also say that the elemental forms are contained "virtually" in the mixt, just as Aristotle had said: the elemental qualities endure, although remitted. ${ }^{27}$

Thomas's criticism of the Arabs applied an irreducible ontological distinction between substantial forms and accidental forms or qualities that will become a standard for subsequent authors. Averroes's thesis on the elemental forms as a medium between a substance and an accident is rejected summarily by Thomas as logically incoherent. A thing is either in a subject (an accident) or is not in a subject (a substance). A medium between a substance and an accident would entail a middle-way between the affirmation and the negation of "being in a subject," which is absurd ("ridiculum est"). ${ }^{28}$

\footnotetext{
${ }^{27}$ De mixt. elem., 123-140: "Considerandum est igitur quod qualitates actiue et passiue elementorum contrarie sunt ad inuicem, et magis et minus recipiunt. Ex contrariis autem qualitatibus que recipiunt magis et minus, constitui potest media qualitas que sapiat utriusque extremi naturam, sicut pallidum inter album et nigrum, et tepidum inter calidum et frigidum. Sic igitur remissis excellentiis qualitatum elementarium, constituitur ex hiis quedam qualitas media que est propria qualitas corporis mixti, differens tamen in diuersis secundum diuersam mixtionis proportionem; et hec quidem qualitas est propria dispositio ad formam corporis mixti, sicut qualitas simplex ad formam corporis simplicis. Sicut igitur extrema inueniuntur in medio quod participat naturam utriusque, sic qualitates simplicium corporum inueniuntur in propria qualitate corporis mixti." Sum. theol. $\mathrm{I}^{\mathrm{a}}$ q. 76 a. 4 ad 4: "Et ideo dicendum est, secundum philosophum in I de Generat., quod formae elementorum manent in mixto non actu, sed virtute. Manent enim qualitates propriae elementorum, licet remissae, in quibus est virtus formarum elementarium. Et huiusmodi qualitas mixtionis est propria dispositio ad formam substantialem corporis mixti, puta formam lapidis, vel animae cuiuscumque.”

${ }^{28}$ De mixt. elem., 68-89: “. . . ulterius procedunt, dicentes quod forme elementorum sunt imperfectissime, utpote materie prime propinquiores; unde sunt medie inter formas substantiales
} 
By keeping the elemental qualities in the mixt, Thomas managed to give a sense of the gradual transformation of matter: qualities act in such a way, through their reciprocal negotiation of contraries, that they prepare the introduction of the new form. Problems of hylomorphic theory aside, we can note that Thomas maintained the causal account of the generation of mixts inherited from Arab Aristotelianism. As opposed to both Avicenna and Averroes, Thomas's view is that acting on each other in order to provoke change can happen only at the level of the qualities, not at the level of the substantial forms. Forms cannot act outside of their own species, although the qualities themselves act only in virtue of their substantial forms. The downside of this account is that it entails the separation in actu between qualities and substantial forms, in order to license the transmigration of qualities from the elements to the mixt. To say that the qualities remain in the mixt without the supporting forms contradicts the generally shared notion that no accident can subsist without its substantial form (unless miraculously). ${ }^{29}$

\section{Duns Sctous's Anti-Aristotelianism}

Scotus is preoccupied with arguing against Averroes and, through him, against Avicenna, ignoring Thomas. This could be explained by the fact that De mixtione elementorum was not a widely circulated work and Thomas's account was not featured prominently in his major works. Because Scotus seems to ignore Thomas's solution completely, it is sometimes difficult to distinguish the differences between the two accounts, especially in what concerns the "virtual permanence" of the elements in the mixt. However, in discussing Averroes, Scotus ends up with a parallel, distinct account, which rejects Aristotle's notion of mixtio. ${ }^{30}$

et accidentales, et sic, in quantum accedunt ad naturam formarum accidentalium, magis et minus suscipere possunt.

Hec autem positio multipliciter improbabilis est. Primo quidem quia esse aliquid medium inter substantiam et accidens est omnino impossibile: esset enim aliquid medium inter affirmationem et negationem. Proprium enim accidentis est in subiecto esse, substantie uero in subiecto non esse; forme autem substantiales sunt quidem in materia, non autem in subiecto: nam subiectum est hoc aliquid; forma autem substantialis est que facit hoc aliquid, non autem presupponit ipsum. Item ridiculum est dicere medium esse inter ea que non sunt unius generis, ut probatur in X Metaphisice, medium enim et extrema ex eodem genere esse oportet; nichil igitur medium esse potest inter substantiam et accidens."

${ }^{29}$ De mixt. elem., 140-145: "Qualitas autem simplicis corporis est quidem aliud a forma substantiali ipsius, agit tamen in uirtute forme substantialis; alioquin calor calefaceret tantum, non autem per eius actionem forma substantialis educeretur in actum, cum nichil agat ultra suam speciem. Sic igitur uirtutes formarum substantialium simplicium corporum in corporibus mixtis saluantur."

${ }^{30}$ Cf. Maier's (1952, 105-108) report on Scotus's views. R. Wood, although she notes that Scotus went as far as to reject Aristotle, follows Maier's assessment of Scotus as developing the Thomist position: "By the fourteenth century, not Averroes but Aquinas had more followers on the subject of mixture, and those followers included not only Dominicans, but Franciscans, 
I will follow Sctous's discussion on II Sent., d. 15 from the Reportata parisiensia (Reportatio 2A, printed in John Duns Scotus 1968, vol. XI, 343345), a mature work dated from the Paris academic year 1302-1303, and the parallel discussion from the Lectura, edited by the Scotist Commission (John Duns Scotus 1950-, vol. XIX, 137-54), dated from the Oxford academic year 1298-1299 or 1300-1301. The Lectura offers a more elaborated and clear redaction than the Reportatio, but both texts cover essentially the same set of arguments, with some notable differences. ${ }^{31}$

\subsection{The Framework of Scotus's Discussion}

Distinction 15 of the second book of the Sentences is concerned with the creation of animals in the fifth and sixth day described by the Book of Genesis. This topic provided an occasion to speak of the generation of mixts from the elements. The connection may not be obvious, but commentators had to explain verses such as Gen. 1:20: "producant aquae reptile animae viventis et volatile super terram sub firmamento caeli" (The Vulgate). The idea that water, a single element, can "produce" complex mixts by itself, such as reptiles and flying animals, would have struck an Aristotelian mind accustomed to the necessity of four elements as odd.

The earlier redaction of d. 15 from the Lectura asks a question closer to the problematic of The Book of Genesis: "Whether in the body of the animal the element out of which the animal is generated remains." The Rep. 2A asks the more direct question on "Whether the elements remain in the mixt." The frame of the discussion, the arguments quod sic and quod non, is important for determining Scotus's perspective, because he contrasts Aristotle with The Book of Genesis. I summarize his argumentation from Rep. 2A, d. 15, q. un., 1-4 in what follows (the Lectura gives the same set).

\subsection{Arguments for the Claim That the Elements Are Not Kept (Quod Non)}

(1) Scotus invokes here Gen. 1:20, on water generating fish. This should be a case of simple generation of substances, involving a corruption of the previous substance. Aristotle's dictum on continuous generation, "the generation of one thing is the corruption of another" ("generatio unius est corruptio alterius," De Gen., I, 3,

such as John Duns Scotus and Ockham" $(2011,262)$. Scotus's main interlocutor, when reading Aristotle, was Averroes, not Thomas. The page on mixture from Gilson (1952, 471-472), offers a short, correct, but insufficient view. On Scotus's natural philosophy, besides Gilson, see Prospero (1955) and Cross (1998).

${ }^{31}$ A shorter version of Reportatio $2 A$, identified by the Vatican editors as Reportatio $2 B$, is not yet edited; the same goes for the part covering Book II of the Sentences from the Additiones Magnae compiled by William of Alnwick. D. 15 of Book II is part of the material that Scotus never revised for the Ordinatio. Wadding and other editors used to complete this part of the Ordinatio with text from various reportationes and from the Additiones. 
318a 23-25), also supports this basic and common understanding of change.

(2) If one element is kept, so should the other three. The elements have different natural places (e.g., fire tends upward while earth tends downward). Consequently, in the case of mixts that float in the air, only one element would be in its natural place (fire), while the other three elements would sit "violently" in the mixt. This should not happen to a proper stable mixt.

(3) A body composed out of contrary elements, such as the mixts, should be able to suffer intrinsic corruption. This is not the case with gold, which endures indefinitely.

\subsection{Arguments for the Claim That the Elements Are Kept (Quod Sic)}

(1) Aristotle, in his definition of the mixt as "a union of altered ingredients," says that the elements are altered, not corrupted $(D e$ Gen. I, 10, 328b 22). Therefore the ingredients are kept. Moreover, a "union" can be applied only to existing things (it has to unite something: unio est entium).

(2) When discussing motion, Aristotle says that mixts are moved in the direction of the predominant element (De Coelo I, 2, 269a 1-2); therefore they have a predominating element which makes them move.

(3) An argument from intrinsic corruption (marcedo): intrinsic corruption, as seen in organic bodies, is explained by Aristotle in terms of the mutual corruption of contrary parts within a whole (Parva naturalia, 5, 469b 21-23 et passim). This can be seen as a proof of elemental composition, because elements are contrary to each other.

Here the Lectura added another argument: the qualities of the elements appear manifestly in the mixt; but according to Aristotle, the qualities cannot be separated from their subject (De An. II, 11, 423a 22-27). It follows that the elements, which act as the subject for the qualities, are also present.

If the quod sic arguments were all taken from Aristotle, the quod non arguments rely mostly on The Book of Genesis or on natural reason. This arrangement of the arguments suggests that Scotus, in supporting the quod non view, will ultimately argue against Aristotle.

\subsection{Two Anti-Aristotelian Theses}

There are two major theses that Scotus puts forward against the Aristotelian theory of mixture: (1) that the four elements do not remain in the mixt at all, neither with respect to their form nor with respect to their qualities, and (2) that mixts are not generated out of the mutual interaction of the 
four elements at all; they are generated either from a single element or from another mixt.

(1) The elements do not remain in the mixt. This thesis is offered as a complete critique of both Avicenna and Averroes. "I hold that the elemental forms do not remain in the mixt, neither according to their essence, nor according to their qualities," says the Lectura, and, similarly, the Rep. 2A: "the substantial forms of the element do not remain in the mixt." 32

The principle of ontological parsimony intervenes here: there is no need to posit a plurality of substantial forms in the mixt. ${ }^{33}$ From experience, there is no operation in the mixt that can be explained unequivocally by the elemental form (Rep. 2A, d. 15, q. un., 5 and Lect. II, d. 15, q. un., $21)$. The thesis can be easily argued for from the theory of hylomorphic composition and from the definition of the substantial form, as Thomas had done. The substantial form is indivisible (atoma) and constitutes a per se substance on its own. Keeping the elemental forms in the mixt would mean keeping in actu five supposits: one for each elemental form, plus one for the forma mixti. This would hardly make a per se subsistens (Rep. 2A, d. 15, q. un., 5; Lect. II, d. 15, q. un., 24). In the same way, one can argue on the basis of the principle that quantity is an immediate property of substance ("quantitas consequatur compositum, sicut passio substantiae corpus"). As such, quantity cannot inhere immediately in five supposits; thus we would have in the mixt five different quantities, a mere juxtaposition (Rep. $2 \mathrm{~A}, \mathrm{~d}$. 15, q. un., 5).

The argument against the permanence of the elemental substantial forms was acquired since Thomas. What is new, at least in the Lectura, is the open rejection of the permanence of the elemental qualities ("... non manent in mixto secundum suas essentias, nec eorum qualitates”). The Reportatio is not as vehement when it comes to this thesis. A text from the Reportatio suggests that Scotus could also allow for the possibility of some operations to be common to the element and to the mixt. Scotus notes: the natural quality of the element does not appear in the mixt, "however, some operations appear to be common to the mixt and to the element, or similar to a certain degree." 34 I know of no other text that supports the permanence of qualities from the elements down to the mixt in Scotus, presented here as a possibility. The Reportatio still argues that the elemental

\footnotetext{
${ }^{32}$ Lect. II, d. 15, q. un., 27: "Ideo est alia opinio, quam teneo, quod formae elementares non manent in mixto secundum suas essentias, nec eorum qualitates." The Lectura uses the word essentia for the substantial form. Rep. 2A, d. 15, q. un., 5: "Dico ad quaestionem, tenendo oppositum utrisque [i.e., Avicenna and Averroes], quod forma substantialis elementi non manet in mixto."

${ }^{33}$ Scotus admits, of course, a plurality of forms in higher mixts, animated beings. See Cross (1998, Ch. 4).

${ }^{34}$ Rep. 2A, d. 15, q. un., 7: "Ad aliud, dico quod non apparet qualitas naturalis elementi in mixto, sed differens specie, perfectior . . . tamen aliquae operationes apparent esse communes mixto et elemento vel similes in aliquo gradu." I thank the anonymous reader who pointed out this passage to me.
} 
qualities are lost in the mixture, but it does appear that Scotus took a step back on this point. With this caveat noted, both texts are clear on the fact that the elemental qualities and the qualities of the mixt belong to different species altogether. ${ }^{35}$ Flesh does not have the same quality that fire does, for animal heat is not the same as the heat of the fire; they are of different species, one more perfect than the other. When a new mixt is produced, new qualities are produced.

It remains for Scotus to present his own view on Aristotle's "virtual permanence" of the elements. Scotus's explanation is that the type of relationship between the elements and the mixt is the same as that between a median quality and the extreme qualities (e.g., between gray and either black or white). Just as the extreme qualities are virtually present in a median quality, so are the elements virtually present in the mixt. They are not locally present as a thing next to a thing (ibi res, et res). His expression is that there is an "agreement" (conventio) between the elements and the mixt, just as there is an agreement between the extreme qualities and the median quality. They simply resemble each other (propter naturalem convenientiam is the expression used by the Lectura). There is a greater similarity (similitudo, in the Reportatio) between the mixt and each one of the four elements than there is between the elements themselves, which are contrary to each other (e.g., gray is closer to either black or white than black is to white). ${ }^{36}$

It is tempting to see in the passages where Scotus explains that the elements remain virtualiter in the mixt the same doctrine as that of Thomas. The elements remain in virtute in the mixt (Rep. 2A, d. 15, q. un., 6), he says, just as the vegetative soul and the sensitive soul remain virtute (Rep.

\footnotetext{
${ }^{35}$ Rep. 2A, d. 15, q. un., 7: “. . . dico quod non apparet qualitas naturalis elementi in mixto, sed differens specie, perfectior tamen, sicut patet primo de Anima, de calore ignis, et mixti animati, quia inanimata non augmentatur proprie, nec nutriuntur, nec calor in carne generat ignem, sed alterat ad carnem generandam." Lect. II, d. 15, q. un., 39: "dico quod qualitates elementorum non manent in mixto, immo qualitates mixti sunt alterius speciei (ut patet per actiones earum, quae sunt alterius speciei)." Lect. II, d. 15, q. un., 40: "dico quod mixtum non habet qualitatem elementi (nam caro non habet qualitatem ignis; unde calor animalis non est calor igneus)."

${ }^{36}$ Rep. 2A, d. 15, q. un., 6, (my emphasis): "Quomodo igitur manent elementa in mixto? Dico quod sicut necesse est convenire medium eiusdem generis cum extremis, sicut vult Commentator, quod calor medius componitur ex extremis, et tamen est simplex, ita quod non plus est ibi res, et res, quam in extremo: sed pro tanto dicitur componi ex extremis, quia est ibi convenientia cum extremo, qualis non est extremi cum alio. Sic elementa manent in mixto, sicut in materia communi, sicut qualitates extremae in medio." Lect. II, d. 15, q. un., 27 holds the same thesis: "Unde non est alia difficultas quomodo forma mixti potest generari ex elementis, quam quomodo qualitas media potest generari ex extremis. Sicut enim ex actione colorum contrariorum generatur forma media, in qua magis assimilantur quam inter se, quae in comparatione ad utrumque non contrariatur utrique,- - sic ex elementis corruptis generatur forma mixti, in quo dicuntur manere sicut in effectu communi. Unde non est alia difficultas quomodo elementa manent in mixto, quam quomodo qualitates contrariae manent in media qualitate generata."
} 
2A, d. 15, q. un., 7) in the intellectual soul. Does it not mean that their operations, powers or virtues are kept? ${ }^{37}$

In light of Scotus's explanation of how it is that the extreme qualities are kept virtually in the median quality-through resemblance-and given his thesis that the elemental qualities are lost in the mixture, it seems that what he means by remanere virtualiter is different than what Thomas means by it. I recall Thomas's phrasing for comparison. For Thomas, the elemental qualities are found (inveniuntur) in the median quality of the mixt, just as the extreme are found in the median, because the median participates in the nature of both extremes (in medio quod participat naturam utriusque). ${ }^{38}$ For Scotus, the extreme qualities and the median quality are of different species altogether; the extremes are not found in the median as res and res, although the median resembles the extremes. In short, Thomas reads Aristotle's formula "salvatur enim virtus eorum" as entailing a permanence of the same qualities, although remitted; for Scotus, the virtual permanence of the elements does not entail a permanence of the same qualities; it only entails the fact that the qualities of the mixt are similar with those of the elements.

In conclusion, the Reportatio, as opposed to the Lectura, seems to allow the possibility of some qualities to endure through the mixture. This suggests the possibility that Scotus's opinion has evolved between the two redactions. However Scotus does not say that the elemental qualities are remitted or that they are kept in the mixt in a remitted state, as Thomas does. ${ }^{39}$ They act on each other so as to generate a median quality, just as in the Arab or in the Thomist account, but once this median quality is generated, they are gone. They remain virtually in the median quality through resemblance. This is a significant departure from Thomas's understanding of Aristotle's requirement for the virtual permanence of the elements in the mixt.

(2) Scotus's second thesis is that mixts are not generated by the mutual corruption of the four elements. ${ }^{40}$ The mutual corruption of all four of them is in fact impossible, he argues.

\footnotetext{
${ }^{37}$ Compare Thomas: "Et hoc est quod Aristotiles dicit in I De generatione: Non manent igitur elementa scilicet in mixto actu ut corpus et album, nec corrumpuntur nec alterum nec ambo: saluatur enim uirtus eorum" (De mixt. elem., in fine) with Scotus: "Unde Aristoteles, quamquam videtur velle contrarium, magis videtur intentio sua pro ista parte. Dicit enim in uno loco quod actualior est forma generati, et potentialior forma elementi, ex quo. Et cum dicit quod manent elementa, subdit, salvatur enim virtus eorum, ideo magis videtur ponere, ipsa manere in virtute, quam secundum formas proprias." (Rep. 2A, d. 15, q. un., 6).

${ }^{38}$ De mixt. elem., 137-147: "Sicut igitur extrema inueniuntur in medio quod participat naturam utriusque, sic qualitates simplicium corporum inueniuntur in propria qualitate corporis mixti... Sic igitur uirtutes formarum substantialium simplicium corporum in corporibus mixtis saluantur."

${ }^{39}$ Sum. theol. I ${ }^{\text {a }}$ q. 76 a. 4 ad 4 quoted earlier ("Manent enim qualitates propriae elementorum, licet remissae").

${ }^{40}$ Rep. 2A, d. 15, q. un., 6: "Ideo dico quod nunquam est necesse quod generetur mixtum ex quatuor elementis concurrentibus, etiamsi concurrant per virtutem divinam, vel qualitercumque, nunquam ex eis generatur mixtum."
} 
Scotus accounts for the generation of mixts through the simple replacement of one form with another form (since forms are the bearer of the individuality of substance in Scotus). There is no difference between the generation of the mixt out of the elements and the generation of a mixt out of another mixt; in both cases, it is a case of the corruption of one form and the introduction of another. ${ }^{41}$ Scotus argues for this account from a robust understanding of substantial generation and corruption. Corruption and generation, as single processes, can involve only two participants: the corrupting agent and the corrupting patient. When water meets fire, one of them corrupts the other one; both cannot be corrupted at the same time. This also applies to the interaction of the four elements, which get corrupted in couples. It is a two-step process: in the first step, the elements corrupt one another in couples (e.g., fire corrupts water and air corrupts earth); in a second step, the two winning elements again act on each other, and one of them finally wins. Therefore a mixt can only be generated out of one element, the element that wins the final. One can say that all four elements concur in the generation of the mixt by selecting the element that wins, but only one of them can be the proximate cause. To say that mixts arise from the mutual corruption of the four elements is logically inconsistent according to Scotus: in the exact moment when the form of the mixt is produced, the elements should be corrupted, and we end up with a case of creation out of nothing. Hence Scotus declares that mixts can be generated only out of another mixt or one single element. ${ }^{42}$

The direct consequence of this view is that Aristotle's theory of mixtio as a process distinct from generation, corruption, and alteration is dropped. Scotus speaks of the generation of fish out of water and of the corruption of wood into fire, not of mixtio. The mixt and the element are incompossible, as a terminus ad quem and a terminus a quo in a process of corruption and generation, just as the elements are incompossible between themselves. ${ }^{43}$

\footnotetext{
${ }^{41}$ Rep. 2A, d. 15, q. un., 6: "Sed materia tota fit sub forma mixti, et eodem modo fieret, si tota illa materia praefuisset sub forma unius elementi." Lect. II, d. 15, q. un., 29: "dicimus quod mixtum generatur ex mixto, sicut patet frequentius: animal ex animali; similiter ex uno elemento generatur mixtum, sicut ex aqua generabantur pisces et animalia volatilia."

${ }^{42}$ Rep. 2A, d. 15, q. un., 6: "Nunc autem se conveniant elementa quatuor, impossibile est quod corrumpant se mutuo. Quia sint duo, A, et B, corrumpentia se mutuo, in isto instanti in quo $\mathrm{B}$ corrumpitur ab A, opportet $\mathrm{A}$ esse, aliter nihil esset corrumpens in actu; igitur in isto instanti non corrumpitur A; igitur si in alio, a B, corrumpitur A, nihil actu manente, adhuc impossibilius est quod corrumpendo se invicem generent mixtum: quia impossibile est formam mixti esse inductam ante instans corruptionis elementorum: igitur in illo instanti inducetur forma mixti ex nihilo agente." Cf. same argument in Lect. II, d. 15, q. un., 30-32.

${ }^{43}$ Rep. 2A, d. 15, q. un., 5: "Item, apparet quod mixtum corrumpitur in unum elementum, ut lignum, in ignem, et ex uno elemento potest mixtum generari, ut habetur ex Scriptura Genes. I. igitur est talis incompossibilitas inter mixtum, et elementum: sicut inter terminum a quo, et terminum ad quem ..."; Lect. II, d. 15, q. un., 23: "Praeterea, mixtum generatur ex elementis, et etiam corrumpitur mixtum in elementa: potest igitur esse terminus 'a quo' et terminus 'ad quem' generationis sicut elementa inter se, quorum unum generatur ex alio et corrumpitur in illud; igitur mixtum et elementum habent incompossibilitatem inter se qualem
} 
This rejection of the Aristotelian theory of mixtio is, to my knowledge, a first in Latin Aristotelianism.

Concerning the causal relationship between the elements and the mixt, Scotus does say that mixts are generated out of another mixt or out of an element, which suggest that the elements act at the level of a material cause. The elements are by no means an efficient cause participating in the generation of the forma mixti, because that would invalidate the order of eminence between an element and a mixt. The argument of authority is Aristotle's principle that the cause must have at least the same degree of perfection as the effect (De Gen. I, 10, 237b 22-26): since the form of the mixt has a higher degree of perfection than the elemental forms, the elemental forms cannot be the cause of the forma mixti. ${ }^{44}$ But do the elements participate in the causation of the forma mixti in any other way?

Scotus's overall strategy goes toward weakening the causal connection between the elements and the mixt. He does so by rejecting different competing theories of the eduction of the form from matter. (1) The Augustinian theory of seminal reasons is discussed at length in d. 18 on Book II of the Sentences. He rejects the Augustianian (Stoic) theory that understands the seminal reasons as inchoate forms into matter. One can say, comments Scotus, that the intermediary mixts act as a seminal reason for the subsequent more perfect mixts, or that the element, as a terminus $a$ quo, acts as a seminal reason for the mixt; but this is not the Augustinian theory. ${ }^{45}$ (2) The Lectura also argues against the more generally accepted theory of those who think that the forma mixti is educed from matter through the mutual corruption of the elements: it is "a wrong understanding" of the process. $^{46}$ (3) Although he deplores those who work in vain at finding out how it is that the four elements descend from their spheres to generate the mixts (this is not what happens at all, since, as we have seen, the mixts are not generated out of the four elements), ${ }^{47}$ Scotus does accept the celestial influence on the elements and on the sublunary bodies, and he does think that the skies induce forms. ${ }^{48}$

habent elementa: sicut igitur unum elementum non manet in alio, ita nec elementum manebit in mixto."

${ }^{44}$ Rep. 2A, d. 15, q. un., 6: "Praeter hoc necesse est agens esse aeque perfectum cum producto, nullum elementum, nec quatuor simul, sunt aeque perfecta cum mixto."

${ }^{45}$ Lect. II, d. 18, q. 1-2 (see especially 49: "Sed quia dictum est supra quod formae elementares non manent in mixto, nec oportet materiam esse sub omnibus formis elementaribus ad hoc quod forma mixti recipiat.") Cf. the corresponding passage on mixts in Rep. 2A, d. 18, q. 1, 13 (less developed). See a detailed account of Scotus's position on seminal reasons in Cross (1998, 40-45). On the Augustinian theory, see Gilson (1929, 169 sq.).

${ }^{46}$ Lect. II, d. 15, q. un., 28-29: "Sed istud male intelligitur ab aliquibus, ac si quattuor elementa primo agerent mutuo et se mutuo corrumperent, et tunc educerent formam aliquam intermediam eorum. Sed istud est impossibile."

${ }^{47}$ Lect. II, d. 15, q. un., 34: "Unde frustra laborant illi qui quaerunt quomodo elementa concurrant ad generationem mixti: aut descenderent de sphaera sua, aut aliunde. —Numquam de facto sic generatur mixtum, sed vel ex alio mixto vel ex uno elemento."

${ }^{48}$ Lect. II, d. 14, q. 3, "Utrum corpora caelestia habeant efficaciam aut aliquam influentiam super ista inferiora" and Rep. 2A, d. 14, q. 3, "Utrum stellae aliquid agant in inferiora." 
The obvious alternative is that in generation a new form has to be created. The cause of the new form is relegated by Scotus to the external agent introducing the new form, acting on the element or on another mixt and generating a new substance out of it. An external and "equivocal" (agens aequivocum, of a different, nobler nature) is needed to corrupt the old form and to introduce a new one. The Lectura appeals even to the "universal agent" to introduce the forma mixti, ${ }^{49}$ while other texts provide the sky as an example of the agent, or any other external, nobler agent. Here is a clear passage on the process:

When a mixt has to be generated out of an element (like a stone out of putrefied matter), first a certain quality appropriate for such a mixt is introduced, and at last the form of the element is corrupted and a certain form of the mixt is introduced by an agent not univocal with the generated body, by a nobler body (like the sky). ${ }^{50}$

The appeal to the celestial influence or to the universal agent in these passages does not mean that natural agents do not introduce forms; forms are efficacious, and any body that is nobler than the generated body can do it. ${ }^{51}$ Scotus describes the gradual transformation of matter as a succession of forms, in a certain natural order, from less perfect to more perfect mixts. A form can inform directly a piece of matter quantum ad perfici, but not quantum ad transmutari: in the order of transmutation, matter cannot pass directly from one form to another, it has to follow a certain order. Wine can pass into vinegar, but not the other way around. ${ }^{52}$ The original element or mixt has to be properly disposed to receive the new form of the generated mixt, and not another form. In this sense, the causal contribution of elemental matter in the generation of the mixt is saved at the level of

\footnotetext{
${ }^{49}$ Lect. II, d. 15, q. un., 29: “. . . Nam quando forma elementi unius in tantum alteratur quod non potest manere sub qualitatibus inductis ipsius alterantis ab agente aequivoco, tunc corrumpitur forma illius elementi et inducitur forma mixti ab agente aequivoco et universali, sicut quando generatur lapis et minera."

${ }^{50}$ Lect. II, d. 18, q. 1-2, 43: "Unde quando ex elemento generari debet mixtum (ut lapis aut putrefactibile), primo inducitur aliqua qualitas proportionata tali mixto, et tandem corrumpitur forma elementi, et ab agente non univoco cum generato sed a corpore nobiliore (ut a caelo) inducitur aliqua forma mixti."

51 On causation in Scotus, see especially Gilson (1952, 343-355, 630 et passim) (630, on essentially ordered causes: "Chaque être second reçoit donc du Premier, par mode de création, une efficacité causale proportionnelle à son être"); see also Sylwanowicz (1996) and Cross (1998, Ch. 3).

${ }^{52}$ Rep. 2A, d. 15, q. un., 9: "Dico quod immediatio formae ad materiam est duplex, vel quantum ad perfici, vel quantum ad transmutari. Primo modo, dico quod forma substantialis immediate recipitur in materia quacunque indifferenter, ita quod immediate. Secundo modo, non immediate, quia ordo est formarum inter se, ita quod aliquae sint priores, aliquae posteriores, ita quod materia non immediate transmutatur a quacunque forma ad aliam, sed ordine quodam; ut immediate post formam vini ad formam aceti, non autem e contra." Scotus argues here against Averroes's objection, mentioned earlier, that the forms of mixts cannot be received immediately in matter, but only through the mediation of elemental forms.
} 
the material cause: an anterior material transformation is necessary for the reception of any form, both to enable and to limit the in-formation. ${ }^{53}$

\section{Conclusions}

Scotus's theory of mixts was not inconsequential. Some of his immediate followers, like Peter of Aquila (1907-1909, Vol. 2, 261-266), copy him indiscriminately. ${ }^{54}$ One important follower is Ockham, who defended Scotus's thesis over the non-permanence of qualities and affirmed, similarly, that the elemental qualities are replaced by equivalent qualities in the mixt. ${ }^{55}$ Thus Scotus's "resemblance" thesis over Aristotle's remanere virtualiter would live on, and one can follow his posterity through Maier's study (Maier 1952, 109 sq.).

After having studied an impressive amount of material on the theory of mixture, Maier's conclusion was that Aristotelianism could not provide a successful solution because hylomorphism was incompatible with the theory of the Empedoclean elements. Aristotelianism was from the start a failed project, and the two parallel descriptions of matter were never rendered fully integrated by Latin authors, according to Maier. She expressed this structural incompatibility as that between a metaphysical doctrine (hylomorphism) and a natural philosophical doctrine (theory of elements). Maier also thought that this failure paved the way for the seventeenthcentury rejection of hylomorphism and the success of corpuscularian and atomistic theories.

Maier's assessment was reminiscent of Duhem's (1902) strong opposition between hylomorphism and atomism as the two irreducible alternatives for any theory of mixture. ${ }^{56}$ As Paul Needham has shown, one should add a third alternative theory of mixture to Duhem's and Maier's opposition between Aristotelianism and atomism: the Stoic one, which paralleled the development of Latin Aristotelianism and enjoyed a certain revival in the Renaissance and in the seventeenth century. Additionally, recent literature has challenged Maier's view according to which an Aristotelian account of mixts was simply not possible. Rega Wood and Michael Weisberg have

\footnotetext{
${ }^{53}$ Cf. on this point Gilson $(1952,434)$, who argues that, for Scotus, attributing a certain degree of actuality to matter is what makes generation and corruption possible.

${ }^{54}$ Most of Peter's account is taken almost literally from the Lectura.

${ }^{55}$ Quodl. III, q. 5: "Tertio dico quod sicut forma elementaris substantialis non manet in mixto, ita nec qualitates eorum manent in qualibet parte mixti . . Quarto dico quod elementa dicuntur manere in mixto quia qualitates aequivalentes qualitatibus elementorum manent" (William Ockham 1967-1988, Vol. 9, 222). (I read Ockham's next explanation on this page, that some elemental qualities "remain" in every part of non-animated bodies, while they "remain" only in some parts of animated bodies, to entail that they "remain" in the qualified sense explained above, as replaced by equivalent qualities of the mixt. Otherwise it seems incoherent with his previous statements.)

${ }^{56}$ See now Needham's (2002) studies on Duhem. For Maier's conclusions, see especially Maier (1952, 3-4, 138-140).
} 
argued that Rufus of Cornwall's theory of mixture satisfied the demands of an Aristotelian theory, and his account was followed by a number of other figures. ${ }^{57}$

In this sense, Scotus is not a success story that should count against Maier's view, because his account rejects the Aristotelian mixture altogether in favor of generation and corruption. The reassessment of Duns Scotus's account of mixture tells us that the structural problems with the Aristotelian theory, which Maier believed were insoluble, were recognized by one major figure. But it also tells us that the rejection of the Aristotelian theory need not be in favor of atomism, or the Stoa for that matter. Scotus still works within the Aristotelian frame of concepts and his account is forged by rigorously determining their use and internal coherence. ${ }^{58}$ Scotus's rejection of mixtio derives ultimately from his understanding of substantial form as an irreducible, inflexible individual: change happens through a succession of individuals, and what endures through change is matter, not form, be it substantial or accidental. ${ }^{59}$ The fact that an account of mixture was given while using both hylomorphic theory and the theory of elements suggests that the two doctrines need not be seen as fully incompatible.

\author{
Lucian Petrescu \\ E-mail : lucian.petrescu@ugent.be
}

\title{
References:
}

Averroes. 1562. Aristotelis Stagiritae de coelo, de generatione et corruptione, meteorologicum, de plantis, cum Averrois Cordubensis variis in eosdem commentariis. Venice: apud Iunctas.

Averroes. 1958. Averroes on Aristotle's De Generatione et corruptione: Middle Commentary and Epitome. Translated by Samuel Kurland. Cambridge, MA: The Medieval Academy of America.

Averroes. 2003. Averrois Cordubensis commentum magnum super libro De celo et mundo Aristotelis. 2 vols. Edited by Rüdiger Arnzen. Leuven: Peeters.

Avicenna. 1987. Avicenna Latinus: liber tertius naturalium de generatione et corruptione. Edited by Simone Van Riet. Leuven: Peeters.

Avicenna. 2009. The Physics of The Healing: A Parallel English-Arabic text. Vol. 1. Translated by Jon McGinnis. Provo, UT: Brigham Young University Press.

Bobik, Joseph. 1988. Aquinas on Matter and Form and the Elements: A Translation and Interpretation of the de Principiis Naturae and the De Mixtione Elementorum of St. Thomas Aquinas. Notre Dame, IN: University of Notre Dame Press.

\footnotetext{
${ }^{57}$ See Wood and Weisberg (2004). Cooper (2004) provides a defense of Aristotle's own account of mixture.

${ }^{58}$ Gilson notes, with his usual penetration, on the real distinction in Scotus: "Toute son habitude de pensée [Scotus's], qui l'incline à la multiplication des moments dans l'analyse, lui fait en revanche éliminer du concret les distinctions réelles chaque fois qu'il peut les éviter. Nous en aurons des preuves, mais aucune plus décisive que sa doctrine du mixte" (1952, 471).

${ }^{59}$ See a discussion of this in Cross (1998, 43 sq.). Cross speaks of "the principle" that "it is not possible that change occurs without the production and/or destruction of an individual thing."
}

Acknowledgements Research for this article was financed by the Fonds Wetenschappelijk Onderzoek Vlaanderen (FWO). I thank Erin Islo and Charles T. Wolfe for reviewing my English, and the anonymous readers for comments. 
Cooper, John M. 2004. “Two Notes on Aristotle on Mixtures.” In Knowledge, Nature and the Good: Essays on Ancient Philosophy, 148-173. Princeton: Princeton University Press.

Cross, Richard. 1998. The Physics of Duns Scotus: The Scientific Context of a Theological Vision. Oxford: Clarendon Press.

D’Alverny, Marie Thérèse. 1961. “Avicenna latinus I.” Archives d'Histoire doctrinale et littéraire du Moyen Âge 28: 284-288.

De Haas, Frans A. J. 1999. "Mixture in Philoponus: An Encounter with a Third Kind of Potentiality." In The Commentary Tradition on De generatione et corruptione: Ancient, Medieval and Early Modern, edited by Johannes M. M. H. Thijssen and Henk A. G. Braakhuis, 21-46. Turnhout: Brepols.

Denis, P. 1954. "Le premier enseignement de saint Thomas sur l'unité de la forme substantielle." Archives d'Histoire Doctrinale et Littéraire du Moyen Âge 21: 139-164.

Duhem, Pierre. 1902. Le mixte et la combinaison chimique. Essai sur l'évolution d'une idée. Paris: C. Naud.

Dumont, Stephen. 2009. "Godfrey of Fontaines and the Succession Theory of Forms at Paris in the Early Fourteenth Century." In Philosophical Debates at the University of Paris in the Early Fourteenth Century, edited by Stephen F. Brown, Thomas Dewender, and Theo Kobusch, 39-125. Leiden: Brill.

Eichner, Hiedrun. 2005. Averroes's mittlerer Kommentar zu Aristoteles' De generatione et corruptione. Mit einer einleitenden Studie versehen, herausgegeben und kommentiert. Paderborn, Munich, Viena, Zürich: Schöningh.

Frede, Dorothea. 2004. "On Generation and Corruption I. 10: On Mixture and Mixables." In Aristotle: On Generation and Corruption, Book I. Symposium Aristotelicum, edited by Frans de Haas and Jaap Mansfeld, 289-314. Oxford: Clarendon Press.

Gilson, Étienne. 1929. Introduction à l'étude de Saint Augustin. Paris: Vrin.

Gilson, Étienne. 1952. Jean Duns Scot. Introduction à ses positions fondamentales. Paris: Vrin.

Hahm, David E. 1985. "The Stoic Theory of Change." The Southern Journal of Philosophy 23 (S1): 39-56. http://dx.doi.org/10.1111/j.2041-6962.1985.tb00425.x.

Joachim, Harold H. 1904. "Aristotle's Conception of Chemical Combination." The Journal of Philosophy 29: 77-86.

Joachim, Harold H. 1922. Aristotlous peri geneseos kai fthoras. Oxford: Clarendon Press.

John Duns Scotus. 1950-. Opera omnia. Edited by the Scotist Commission. Vatican City: Typis Vaticanis.

John Duns Scotus. 1968. Opera omnia. 12 vols. Edited by Luke Wadding. Hildesheim: Olms. Lewis, Eric. 1988. "Diogenes Laertius and the Stoic Theory of Mixture." Bulletin of the Institute of Classical Studies 35 (1): 84-90. http://dx.doi.org/10.1111/j.2041-5370.1988. tb00202.x.

Maier, Anneliese. 1952. An der Grenze von Scholastik und Naturwissenschaft. Rome: Edizioni di Storia e letteratura.

Maier, Anneliese. 1968. Zwei Grundprobleme der Scholastischen Naturphilosophie: Das Problem der intensiven Gröse. Rome: Edizioni di Storia e Letteratura.

Needham, Paul. 2002. "Duhem's Theory of Mixture in the Light of the Stoic Challenge to the Aristotelian Conception." Studies in History and Philosophy of Science Part A 33 (4): 685-708. http://dx.doi.org/10.1016/S0039-3681(02)00023-7.

Pasnau, Robert. 2011. Metaphysical Themes, 1274-1671. Oxford: Oxford University Press. Peter of Aquila. 1907-1909. Commentaria in quatuor Libros Sententiarum magistri Petri Lombardi. 4 vols. Edited by Cyprian Paolini. Levanto: Conv. Ssmae Annuntionis.

Prospero, Stella. 1955. L'ilemorfismo di G. Duns Scoto: saggio. Turin: Societá Editrice Internazionale.

Rashed, Marwan. 2005. "Introduction.” In Aristotle. De la generation et la corruption. Paris: Les Belles Lettres. 
Sorabji, Richard. 1988. Matter, Space and Motion: Theories in Antiquity and Their Sequel. London: Duckworth.

Sorabji, Richard. 2005. The Philosophy of the Commentators, 200-600 AD: A Sourcebook. Vol. 2. Ithaca, NY: Cornell University Press.

Stone, Abraham D. 2008. "Avicenna's Theory of Primary Mixture." Arabic Sciences and Philosophy 18 (1): 99-119. http://dx.doi.org/10.1017/S0957423908000489.

Sylla, Edith. 1991. The Oxford Calculators and the Mathematics of Motion 1320-1350. New York: Garland.

Sylwanowicz, Michael. 1996. Contingent Causality and the Foundations of Duns Scotus's Metaphysics. Leiden: Brill.

Thomas Aquinas. 1882-. Opera omnia iussu Leonis XIII P. M. edita. Rome: S. C. de propaganda fide.

Todd, Robert B. 1976. Alexander of Aphrodisias on Stoic Physics: A Study of the De Mixtione with Preliminary Essays, Text, Translation and Commentary. Leiden: Brill.

van Riet, Simone. 1999. "Le De generatione et corruptione d'Avicenne dans la tradition latine." In The Commentary tradition on Aristotle's De Generatione et corruptione: Ancient, Medieval and Early Modern, edited by Johannes M. H. H. Thijssen and Henk A. G. Braakhuis, 69-78. Turnhout: Brepols.

William Ockham. 1967-1988. Opera philosophica et theologica. 17 vols. Edited by Gedeon Gál, et al. St. Bonaventure, NY: The Franciscan Institute.

Wippel, John F. 2000. The Metaphysical Thought of Thomas Aquinas: From Finite Being to Uncreated Being. Washington: The Catholic University of America Press.

Wood, Rega. 2011. "The Influence of Arab Aristotelianism on Scholastic Natural Philosophy." In The Cambridge History of Medieval Philosophy, edited by Robert Pasnau and Christina Van Dyke, Vol. 1, 259-265. Cambridge: Cambridge University Press.

Wood, Rega and Michael Weisberg. 2004. "Interpreting Aristotle on Mixture: Problems About Elemental Composition from Philoponus to Cooper." Studies in History and Philosophy of Science Part A 35 (4): 681-706. http://dx.doi.org/10.1016/j.shpsa.2004.02.002.

Zabarella, Giacomo. 1604. De rebus naturalibus libri XXX. 10th edn. Paris: Robert Meietti. 